\title{
IDENTIFICATION OF EX-ANTE AND EX-POST TRANSACTION COSTS IN INDUSTRIAL CONSTRUCTION ENGINEERING PROJECTS
}

\author{
Fábio Bellotti da FONSECA ${ }^{1}$, Rosangela Maria VANALLE², João Alberto CAMAROTTO³ \\ ${ }^{1}$ Universidade Nove de Julho, Rua Vergueiro, 235/249, CEP01504-000, São Paulo - SP - Brazil \\ ${ }^{2}$ Department of Industrial Engineering, Universidade Nove de Julho, Rua Vergueiro, 235/249, \\ CEP01504-000, São Paulo, São Paulo - SP - Brazil \\ ${ }^{3}$ Department of Industrial Engineering Universidade Federal de São Carlos - SP - Brazil
}

Received 27 February 2018; accepted 25 June 2018

\begin{abstract}
Construction costs comprise not only production but also transaction costs, which can be categorized as exante (pre-contractual) and ex-post (post-contractual) costs. No evidence has been found in the literature of research about transaction costs in industrial construction engineering projects. The objective of this paper is to identify ex-ante and expost transaction costs in industrial engineering construction projects. To accomplish this, empirical research with 4 case studies was conducted with a large engineering firm in Brazil. This research not only identified transaction costs already found by others, dividing them into ex-ante and ex-post, but also identified that travel, RFP clarification, support to strategic decisions of the owner and knowledge transfer are transaction costs not previously identified in the researched literature but that are very relevant to the respective subject. Therefore, this research confirms that transaction costs should be considered ex-ante and ex-post by owners and contractors in industrial construction engineering projects and enlightens academics and practitioners on ways to achieve the reduction of such costs.
\end{abstract}

Keywords: transaction cost, TC, industrial construction, engineering projects, strategic decisions.

\section{Introduction}

Transaction costs arise from economic exchange rather than from production activities. A transaction occurs when a good or service is transferred across a technologically separable interface (Williamson 1985). In addition to the cost of production, there are also transaction costs to be considered (Winch 1989). While production costs are the costs of transforming inputs into outputs, transaction costs arise from economic exchange. The costs incurred by activities such as preparing a bid document, estimating, drawing up a contract, administering the contract, and dealing with any deviations from contract conditions are also important. These costs are known as transaction costs, in the study of economic organizations (Coase 1937).

Williamson (1985) defined that transaction costs are a combination of ex-ante (pre-contractual) and ex-post (post-contractual) costs. It is not clear whether transaction costs are higher at the pre- or post-contract phases of a construction project, in private or public projects, in different project delivery systems, and in different types of contracts.
Alchian and Woodward (1988), deepening the opportunistic behaviour research, introduced the quasi-rent concept, in which one of the parties finds itself in the advantage of extorting the other intentionally due to the contract conditions, using hold-up possibilities.

Li et al. (2012a, 2012b, 2015) affirm that construction projects are composed of not only production costs but also many other transaction costs, which are considered as mainly external costs, and they also affirm that transaction costs have not been well recognized by the industry.

The transaction paradigm has received considerable attention by academics and has been applied to a variety of construction-related topics, including the measurement of transaction costs (Ho, Tsui 2009; Solino, Gago de Santos 2009; Farajian 2010), project organization and governance (Muller, Turner 2005; Jobin 2008), construction contracts (Bajari, Tadelis 2001), construction market and subcontracting (Miller et al. 2002; Lai 2000), and project delivery systems (Whittington 2008). The majority of these studies on transaction costs in construction projects have focused on the theoretical and qualitative aspects of this issue.

*Corresponding author. E-mail: rvanalle@uni9.pro.br 
However, the term "transaction cost" is not consistently defined in the construction industry because the concept of transaction cost is not universally accepted by all stakeholders in construction projects. As a result, empirical studies are few and conflicting because accessing data on transaction costs is problematic, and the interpretation of the data is difficult (Li et al. 2014).

The objective of this paper is to identify transaction costs involved in industrial construction engineering projects, with the proposition that it is possible to identify such costs ex-ante and ex-post. For this, semi-structured interviews were performed in Brazil with project managers of a renowned international consulting and engineering firm responsible for engineering projects across different industries. The global industrial engineering market in 2016 comprised total revenue of US\$3.05 billion (ENR 2017).

Most engineering firms and project owners follow the front-end loading (FEL) methodology, which is aimed at assuring that sufficient information is provided during the conceptual and basic design phase and allows owners to influence the project at early stages prior to detail design, thereby influencing the final cost of a project (Batavia 2001).

\section{Literature review}

To ensure an extensive bibliographic review of transaction costs involved in the construction industry, specifically in industrial constructions, the following key words were defined with their respective cognates: Transaction Cost, TCT (Transaction Cost Theory), TCE (Transaction Cost Economics), construction, engineering, architecture, construction, engineering, design. These words allowed us to better define the set of key words to be searched in the databases: Science Direct, Emerald, Scopus, Scielo, Capes, Proquest, Google Scholar and IEEE, which were:

$$
\begin{aligned}
& \text { - "transaction cost", "architecture"; } \\
& \text { - "transaction cost", "construction"; } \\
& \text { - "transaction cost", "engineering"; } \\
& \text { - "transaction cost", "design". }
\end{aligned}
$$

As a result, until April 23rd, 2017, such research had returned a total of one hundred and one articles, of which twenty-nine articles related to industrial construction projects were selected. Aiming to identify the evolution of the knowledge, all articles were tabulated in an Excel spreadsheet with relevant bibliometric data and organized in ascending order from the first publication. During the reading of each article, the analysis of the bibliographic references was carefully done in an effort to identify if any relevant article had not been identified during the research in the mentioned databases. In this process, despite not researching industrial construction projects, the reference papers of Eccles (1981) and Walker and Wing (1999) were included, bringing the total to thirty-one. The discarded articles, such as articles on residential buildings, engineering and software architecture, financial engineering, among others, were not related to the subject studied.
As applied to construction, the scientific production on the subject originated with Eccles (1981), who argued that Williamson's (1979) reference framework on transaction costs needed to be modified to suit the construction industry and proved through a survey that, due to the specific characteristics of the industry, the contractor and subcontractors, including the engineering firm, usually form a stable organization called a "quasi-firm", which is analogous to the internal contracting system defined by Williamson (1975). Eccles (1981) identified the transaction costs in this process as the costs of overhead, supervision, hiring and firing of those involved in the project.

Reve and Levitt (1984) analysed the trilateral governance, which involves the owner, the engineering firm and the construction company, and they concluded thereby that companies create clan-like relationships in which the engineering firm and the construction company help themselves in the construction process since they end up creating a vicious relationship in which the engineering firm depends on its reputation for future projects and the construction company needs the engineering firm to be called for future bids. Thus, transaction costs were identified as the costs of the professionals who are assigned to take care of the project and the costs associated with the creation of steering meetings to review the engineering project due to lack of confidence and aimed at reducing over-engineering, design and additional hours of engineering for new technologies. The standardization of processes in order to reduce transaction costs was suggested, and the authors concluded that clan formation between companies reduces such costs since companies tend to know each other better, consequently reducing the interest in opportunism.

Winch (1989) identified that the companies involved in a project formed a coalition and proposed to analyse the different interests of each member company through the transaction costs perspective. Based on Williamson's (1985) framework, since construction projects are considered those with high asset specificity and with non-recurring relations, the structure should be hierarchical and not market-based, i.e., not governed by the framework of the construction market. The answer to such divergence is that the make or buy decision in the industry is defined by the source of uncertainties and the complexity found in construction companies. The costs of uncertainties, such as task, climate, organizational and contractual uncertainties, were identified as the main transaction costs.

Aiming to understand the inter-firm supply chain coordination process in construction projects, Formoso et al. (2011), using the coordination theory and transaction cost theory perspective, analysed three theoretical perspectives and concluded that project managers find it difficult to manage the supply chain as they evolve from the project and end up delegating important contract tasks to others at the operational level. They also found that the organizational structure needs to be adapted so as not to fall into this trap, avoiding higher transaction costs. They also identified that project uncertainty is often high because 
engineering and construction projects happen in parallel and engineering design and design review meetings are transaction costs.

Winch (2001) presented a conceptual framework to understand the governance of the construction project process, covering different transactions, used to meet customer demands. The result was that only in the face of repetitive transactions can the parties get to know each other better and that future relationships possibilities outweigh opportunism. In this study, it was identified that, due to its importance, project engineering should be structured in the form of a hierarchy and not market-based, but this was not deemed feasible due to low transaction frequency.

For engineering firms, the trivial compromise is reputation since the loss of reputation in the market for this type of company can be a fatal penalty and that such fear increases the incentive for the company to perform as wished (Winch 1989).

Zerjav et al. (2011) examined the process of designing and executing projects in six multinational engineering firms and were able to conclude that engineering design can be considered an intra-firm transaction relationship between the main office and a number of other offices.

Li et al. (2012a) set out to identify methods to minimize the transaction costs of the owners by means of a structural equation model. They found that the costs can be reduced if the uncertainties diminished and that the engineering design should be completed as soon as possible before the RFP is sent to construction contractors, to allow the contractor to become involved at the beginning of the engineering project, to agree on the division of risks with the construction contractors, to better understand the contractor's behaviour and to pay attention to the efficiency of project management.

In another research, Li et al. (2012b) analysed the effects related to the transaction and the performance of a project, considering performance defined as the project having been completed within the budget, schedule, and in line with the standards of quality and customer satisfaction. They concluded that project performance may be better if the uncertainties in the transactional environment are diminished and if the owner and contractor are sensitive to transaction-related issues. The authors identified transaction costs as those related to conducting market research, exploring financial opportunities, conducting feasibility studies, organizing the bid, negotiating and managing the engineering project, administering the contract, administering the scope of changes and financial litigation, resolving disputes, and managing incentives.

Lu et al. (2015a) analysed post-contractual transaction costs related to disputes in the construction industry and, through a survey, concluded that it is possible to consider six factors that impact transaction costs: reputation, cooperation, confidence, emotion, time schedule, and execution of judgements, of which the most severe transaction costs for the contracting party are reputational damage and the impossibility of future cooperation, and, for the contractor, the project delay is the most impactful transaction cost.

In order to analyse the factors that affect transaction costs in construction projects, Li et al. (2015) considered transaction costs as those incurred by the firm when transacting with another company. They also considered that the factors that affect transaction costs in construction projects can be categorized into the following: a) the role of the owner, b) the role of the contractor, c) efficiency in project management, and d) the transactional environment. The authors divided the transaction costs between pre-contractual (ex-ante) and post-contractual (ex-post) costs. The pre-contractual costs are characterized by costs before effective signature and include external costs, such as technical, legal and financial advice, and internal costs, such as the cost of preparing the project. The post-contractual costs included costs incurred after contract signature but before the construction are effectively completed.

Factors related to project management that affect transaction costs are related to the leadership capacity, decision and communication quality, conflict management, and technical competence. In addition, the characteristics of the transactional environment seem to have an impact on the magnitude of transaction costs. The authors also mentioned that transaction costs are affected by all items related to project complexity, uncertainties, engineering completeness, contractor involvement, competition between bidders, level of interaction between engineering and construction, required guarantees, incentive and disincentive clauses, and allocation of risks (Li et al. 2015).

Lu et al. (2015b) conducted another study in which they developed empirical research using more than two hundred and twenty-five agents from the Chinese construction industry, including contractors, contractors, engineering firms and supervisors, which resulted in a finding that opportunism contrasted with confidence in projects, affects the success of the project, and should be considered a transaction cost. They also reported that the relationship between opportunism and trust is influenced by the level of uncertainty of a project and not by the complexity of the project.

Pang et al. (2015) attempted to improve the understanding of opportunism in construction by identifying pitfalls and the likelihood of occurrence and concluded that incomplete contracts are the main pitfalls for opportunism.

Jiang et al. (2017) discussed the relationship between trust and control through a survey of Chinese builders and concluded that the higher the trust between agents was, the lower the transaction costs related to control. Table 1 shows the summary information on transaction costs in industrial constructions, from the literature. 
Table 1. Evolution of the literature - transaction costs in industrial constructions

\begin{tabular}{|c|c|c|c|c|c|c|c|c|c|c|c|c|c|c|c|c|c|c|c|c|c|c|c|}
\hline \multicolumn{24}{|c|}{ Transaction costs in industrial construction } \\
\hline Author & $\underset{\tilde{U}}{\mathscr{E}}$ & 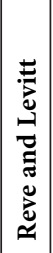 & $\mid \begin{array}{l}\tilde{z} \\
\mathbf{Z} \\
\mathbf{3}\end{array}$ & 节 & 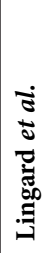 & 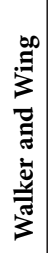 & $\mid \begin{array}{l}\tilde{y} \\
\vdots \\
z \\
z\end{array}$ & 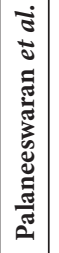 & 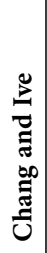 & 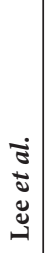 & 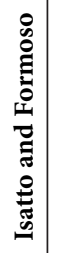 & 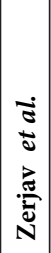 & $\mid \begin{array}{c}\dot{J} \\
\tilde{J} \\
\ddot{J}\end{array}$ & $\begin{array}{l}\vec{J} \\
\vec{J} \\
: \vec{J}\end{array}$ & 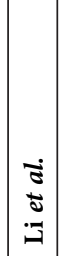 & $\left|\begin{array}{l}\tilde{J} \\
\tilde{J} \\
\Xi\end{array}\right|$ & 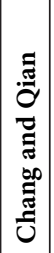 & 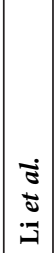 & $\left|\begin{array}{l}\vec{J} \\
\pm \\
\Xi \\
\Xi\end{array}\right|$ & 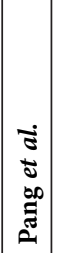 & 毒 & $\begin{array}{l}j \\
0 \\
J \\
o \\
0 \\
0\end{array}$ & 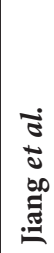 \\
\hline Year & $\vec{\infty}$ & \begin{tabular}{l}
\multirow{2}{*}{} \\
$\stackrel{2}{二}$
\end{tabular} & $\begin{array}{l}\stackrel{2}{=} \\
\stackrel{2}{二}\end{array}$ & $\stackrel{2}{2}$ & $\stackrel{\infty}{2}$ & बे & $\overrightarrow{\stackrel{\sim}{~}}$ & 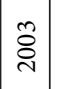 & ڤે̀) & ठे & $\overrightarrow{\vec{i}}$ & $\stackrel{\sim}{\overrightarrow{2}}$ & $\begin{array}{l}\widetilde{J} \\
\stackrel{\sim}{\Xi}\end{array}$ & $\begin{array}{l}\vec{\pi} \\
\stackrel{乛}{\sim}\end{array}$ & $\underset{\sim}{\stackrel{\sim}{\sim}}$ & 兑 & $\stackrel{n}{\stackrel{2}{\sim}}$ & $\stackrel{n}{\stackrel{2}{2}}$ & 吕 & $\stackrel{n}{2}$ & $\stackrel{n}{\stackrel{n}{*}}$ & $\stackrel{0}{\stackrel{0}{\circ}}$ & $\vec{\partial}$ \\
\hline Technical, legal and financial advice & & & & & & & & & & & & & & & & & & $\mathrm{X}$ & & & & & \\
\hline Fair allocation of risks & & & & & & & & & & & & & $\mathbf{X}$ & & $\mathbf{X}$ & & & $\mathbf{X}$ & & & & $\mathbf{X}$ & \\
\hline Learning & & $\mathrm{X}$ & & & & & & & & & & & & & & & & & & $\mathrm{X}$ & & & \\
\hline Project delay & & & & & & & & & & & & & & & & $\mathrm{X}$ & & & & & & & \\
\hline Decision-making a bility & & & & & & $\mathbf{X}$ & & & & & & & $\mathbf{X}$ & & $\mathbf{X}$ & & & $\mathbf{X}$ & & & & & \\
\hline Leadership ability & & & & & & & & & & & & & $\mathrm{X}$ & & & & & $\mathrm{X}$ & & & & & \\
\hline Change order & & & & & & & & & & & & & $\mathrm{X}$ & $\mathrm{X}$ & & & & $\mathrm{X}$ & & & & & \\
\hline Technical competence & & & & & & & & & & & & & $\mathrm{X}$ & & & & & $\mathrm{X}$ & & & & & \\
\hline Competition between bidders & & & & & & & & & & & & & $\mathrm{X}$ & & & & & $\mathrm{X}$ & & & & $\mathrm{X}$ & \\
\hline Engineering completeness & & & & $\mathbf{X}$ & & & & & & & & & $\mathbf{X}$ & $\mathbf{X}$ & $\mathbf{X}$ & & & $\mathbf{X}$ & & & & $\mathbf{X}$ & \\
\hline Effective Complexity & & & & & & & & & & & & & $\mathrm{X}$ & & $\mathrm{X}$ & & & $\mathrm{X}$ & & & & & \\
\hline Contractor behavior & & & & & & & & & & & & & & & & & & & & & & $\mathrm{X}$ & \\
\hline Contractor behavior & & & & & & & & & & & & & & & & & & & & & & $\mathrm{X}$ & \\
\hline Bidding behavior & & & & & & & & & & & & & & $\mathrm{X}$ & & & & $\mathrm{X}$ & & & & & \\
\hline Communication & & & & & & & & & & & & & $\mathrm{X}$ & & & & & $\mathrm{X}$ & & & & & \\
\hline Confidence & & & & & & & & & & & & & & & & $\mathrm{X}$ & & & $\mathrm{X}$ & & & & $\mathrm{X}$ \\
\hline Management board & & $\mathrm{X}$ & & & & & & & & & & & & & & & & & & & & & \\
\hline Constructability & & & & & & & & & & & & & & & & & & & & & & $\mathrm{X}$ & \\
\hline Hiring and resignation & $\mathrm{X}$ & & & & & $\mathrm{X}$ & & & & & & & & & & & & & & & & & \\
\hline Control taxpayers & & & & & & $\mathrm{X}$ & & & & & & & & & & & & & & & & & \\
\hline Cooperation & & & & & & & & & & & & & & & & $\mathrm{X}$ & & & & & & & \\
\hline Project preparation cost & & & & & & & & & & & & & & & & & & $\mathrm{X}$ & & & & & \\
\hline Costs of non-adaptation & & & & & & & & & & & & & & & & & & $\mathrm{X}$ & & & & & \\
\hline Bargain costs & & & & & & & & & & & & & & & & & & $\mathrm{X}$ & & & & & \\
\hline Goal Setting & & & & & & $\mathrm{X}$ & & & & & & & & & & & & & & & & & \\
\hline Definition of policies and objectives & & & & & & $\mathrm{X}$ & & & & & & & & & & & & & & & & & \\
\hline Deviation from contract & & & $\mathrm{X}$ & & & & & & & & & & & & & & & $\mathrm{X}$ & & & & & \\
\hline \multicolumn{24}{|l|}{ Feature availability } \\
\hline Organizational efficiency & & & & & & & & & & & & & $\mathrm{X}$ & & & & & $\mathrm{X}$ & & & & & \\
\hline Elaboration of estimates & & & & & & & & & & & & & & & & & & $\mathrm{X}$ & & & & & \\
\hline Emotion & & & & & & & & & & & & & & & & $\mathrm{X}$ & & & & & & & \\
\hline Early involvement of the contractor & & & & & & & & & & & & & $\mathbf{X}$ & & $\mathbf{X}$ & & & $\mathbf{X}$ & & & & $\mathbf{X}$ & \\
\hline Governance structure & & & & & & $\mathrm{X}$ & & & & & & & & & & & & & & & & & \\
\hline Organizational structure & & & & & & & & & & & $\mathrm{X}$ & & & & & & & & & & & & \\
\hline Viability study & & & & & & & & & & & & & & $\mathrm{X}$ & & & & & & & & & \\
\hline Enforcement of judgments & & & & & & & & & & & & & & & & $\mathrm{X}$ & & & & & & & \\
\hline Experiences in similar projects & & & & & & & & & & & & & $\mathbf{X}$ & & $\mathbf{X}$ & & & $\mathbf{X}$ & & & & $\mathbf{X}$ & \\
\hline Frequency of lawsuits & & & & & & & & & & & & & $\mathrm{X}$ & & & & & & & & & & \\
\hline Conflict management & & & & & & & & & & & & & $\mathrm{X}$ & & & & & $\mathrm{X}$ & & & & & \\
\hline Incentive management & & & & & & & & & & & & $\mathrm{X}$ & $\mathrm{X}$ & & & & & & & & & & \\
\hline Project management & & $\mathbf{X}$ & & & & $\mathbf{X}$ & & & & & & & $\mathbf{X}$ & & & & & $\mathbf{X}$ & & & & & \\
\hline Engineering management & & & & & & & & & & & & & & $\mathrm{X}$ & & & & & & & & & \\
\hline Subcontractor management & & & & & & & & & & $\mathrm{X}$ & & & & & & & & & & & & & \\
\hline
\end{tabular}


End of Table 1

\begin{tabular}{|c|c|c|c|c|c|c|c|c|c|c|c|c|c|c|c|c|c|c|c|c|c|c|c|c|c|}
\hline \multicolumn{26}{|c|}{ Transaction costs in industrial construction } \\
\hline Author & $\frac{\mathscr{E}}{\tilde{U}}$ & 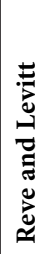 & 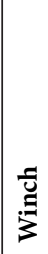 & 䒕 & 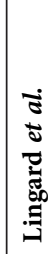 & 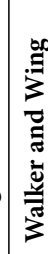 & 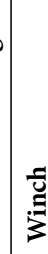 & 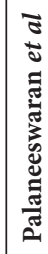 & 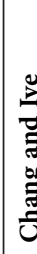 & 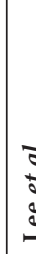 & & 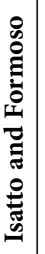 & 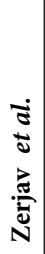 & $\begin{array}{c}\overrightarrow{0} \\
\tilde{J} \\
0\end{array}$ & 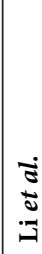 & 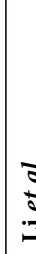 & & $\begin{array}{l}\overrightarrow{5} \\
\tilde{J} \\
\Xi\end{array}$ & 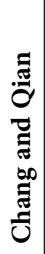 & 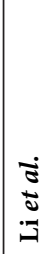 & $\begin{array}{l}\dot{J} \\
\tilde{J} \\
\Xi\end{array}$ & 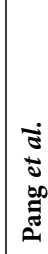 & 竎 & 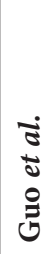 & 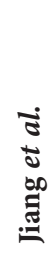 \\
\hline Year & $\vec{\circ}$ & 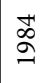 & $\stackrel{\circ}{\stackrel{一}{\sigma}}$ & $\stackrel{2}{2}$ & $\stackrel{\infty}{\stackrel{2}{-}}$ & Әे & $\overrightarrow{\mathrm{d}}$ & $\stackrel{\overbrace{}}{\stackrel{\sim}{े}}$ & $\widehat{\stackrel{े}{~}}$ & ¿े & & $\overrightarrow{\vec{\sim}}$ & $\stackrel{\sim}{\sim}$ & 胥 & 胥 & $\stackrel{i}{a}$ & , & 空 & $\stackrel{n}{\stackrel{n}{2}}$ & in & 党 & $\stackrel{n}{\stackrel{4}{\sim}}$ & $\stackrel{n}{\stackrel{n}{n}}$ & 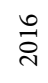 & $\widehat{\stackrel{\sim}{~}}$ \\
\hline Hold up & & & & & & & & & $\mathrm{X}$ & & & & & & & & & & $\mathrm{X}$ & & & & & & \\
\hline Impossibility of future cooperation & & & & & & & & & & & & & & & & & & $\mathrm{X}$ & & & & & & & \\
\hline Uncertainties & & & & & & & & & & & & & & $\mathrm{X}$ & & & & & & $\mathrm{X}$ & & & & & \\
\hline Information & & & & & & & & & & & & & & & & & & & & & & & $\mathrm{X}$ & & \\
\hline Integrate contributions & & & & & & $\mathrm{X}$ & & & & & & & & $\mathrm{X}$ & & & & & & & & & & & \\
\hline Engineering and construction interaction & & & & & & & & & & & & & & & & & & & & $\mathrm{X}$ & & & & $\mathrm{X}$ & \\
\hline $\begin{array}{l}\text { Bad relationship (punctual payment, } \\
\text { interaction, etc.) }\end{array}$ & & & & & & & & & & & & & & & & $\mathrm{X}$ & & & & & & & & & \\
\hline Maintain governance structure & & & & & & & & & & & & & & & & & & & & $\mathrm{X}$ & & & & & \\
\hline Performance monitoring & & & & & & $\mathrm{X}$ & & & $\mathrm{X}$ & $\mathrm{X}$ & & & & & & & & & & & & & & & \\
\hline Set up engineering team & & & & & & $\mathrm{X}$ & & & & & & & & & & & & & & & & & & & \\
\hline Negotiation of contracts & & & & & & & & & $\mathrm{X}$ & & & & & & & & & & & & & & & & \\
\hline Negotiation of lawsuits & & & & & $\mathrm{X}$ & & & & & & & & $\mathrm{X}$ & & & & & & & $\mathrm{X}$ & & & & & \\
\hline \multicolumn{26}{|l|}{ Price negotiation } \\
\hline Future business & & & & & & & $\mathrm{X}$ & & & & & & & & & & & & & & & & & & \\
\hline Financial opportunity & & & & & & & & & & & & & & & $\mathrm{X}$ & & & & & & & & & & \\
\hline Organize governance structure & & & & & & & & & & & & & & & & & & & & $\mathrm{X}$ & & & & & \\
\hline Overhead & $\mathrm{X}$ & & & & & & & & & & & & & & & & & & & & & & & & \\
\hline Punctual payment & & & & & & & & & & & & & & $\mathrm{X}$ & & $\mathrm{X}$ & & & & $\mathrm{X}$ & & & & & \\
\hline Market research & & & & & & & & & & & & & & & $\mathrm{X}$ & & & & & & & & & & \\
\hline Engineering planning & & & & & & & & & & & & $\mathrm{X}$ & & & & & & & & & & & & & \\
\hline Bargaining power & & & & & & & & & & & & & & & & & & & $\mathrm{X}$ & & & & & & \\
\hline Deadline & & & & & $\mathrm{X}$ & & & & & & & & & & & & & $\mathrm{X}$ & & & & & & & \\
\hline Contract preparation and administration & & & & & & & & & & & & & & & $\mathrm{X}$ & & & & & $\mathrm{X}$ & & & & & \\
\hline Preparation and evaluation of edicts & & & & & & & & & & & & & & & $\mathrm{X}$ & & & & & $\mathrm{X}$ & & & & & \\
\hline Price pressure in contract negotiation & & & & & & & & $\mathrm{X}$ & & & & & & & & & & & & & & & & & \\
\hline Search for suppliers & & & & & $\mathrm{X}$ & & & & $\mathrm{X}$ & $\mathrm{X}$ & & & & & & & & & & & & & & & \\
\hline Search for capital equipment & & & & & & & & & & $\mathrm{X}$ & & & & & & & & & & & & & & & \\
\hline Engineering project & & & & & & & & & & & & $\mathrm{X}$ & & $\mathrm{X}$ & & & & & & & & & & & \\
\hline Quality required & & & & & $\mathrm{X}$ & & & $\mathrm{X}$ & & & & & & & & & & & & & & & & & \\
\hline Qualification of the contractor & & & & & & & & & & & & & & $\mathrm{X}$ & & & & & & $\mathrm{X}$ & & & & & \\
\hline Reward (bonus and malus) & & & & & & & & & & & & & & $\mathrm{X}$ & & & & & & $\mathrm{X}$ & & & & $\mathrm{X}$ & \\
\hline Intrafirm relationship & & & & & & & & & & & & & $\mathrm{X}$ & & & & & & & & & & & & \\
\hline Harmonious relationship & & & & & & & & & & & & & & & & & & & & & & & & $\mathrm{X}$ & \\
\hline Relationship Old and subcontracted clients & & & & & & & & & & & & & & $\mathrm{X}$ & & & & & & $\mathrm{X}$ & & & & $\mathrm{X}$ & \\
\hline Relationship with third parties & & & & & & & & & & & & & & $\mathrm{X}$ & & $\mathrm{X}$ & & & & & & & & & \\
\hline Contractor / Contractor relationship & & & & & & & & & & & & & & & & & & & & $\mathrm{X}$ & & & & & \\
\hline Reputation & & & & & & $\mathrm{X}$ & & & & & & & & & & & & $\mathrm{X}$ & & & & & & & \\
\hline Warranty requirement & & & & & & & & & & & & & & $\mathrm{X}$ & & & & & & $\mathrm{X}$ & & & & $\mathrm{X}$ & \\
\hline Settlement of disputes & & & & & $\mathrm{X}$ & & & & & $\mathrm{X}$ & & & $\mathrm{X}$ & & & & & & & & & & & & \\
\hline Engineering design review & & & & & & & & & & & & $\mathrm{X}$ & & & & & & & & & & & & & \\
\hline Replacement of materials & & & & & & & & & & & & & & $\mathrm{X}$ & & & & & & $\mathrm{X}$ & & & & & \\
\hline Supervision & $\mathrm{X}$ & & & & & & & & & & & & & & & & & & & & & & & & \\
\hline
\end{tabular}




\section{Research method}

The present work is an empirical research based on a qualitative approach and an exploratory purpose using case studies. Since the proposition of the present research is theoretical and considering that the transaction costs can be different ex-ante and ex-post, thereby generating opposite results, in order to validate this proposition, four case studies were considered, which are aligned with the recommendations made by Yin (2015).

The chosen organization in which these case studies were conducted is an international consulting and engineering firm that has existed for several decades in Brazil. The choice of the company studied, the choice of the respective projects, and the objects of the case studies were made by convenience.

Eisenhardt (1989) suggests that multiple sources allows a better analysis of the research and, aiming for similarity in the results, all case studies are related to detail engineering design for industrial construction projects. The researcher conducted 4 semi-structure interviews personally, with the respective project managers of each studied case, in which each one belonged to different business units of the firm, assuring a broader base. All project managers are Engineers with PMP (Project Management Professional) certification. A questionnaire with closed questions was utilized covering ex-ante and ex-post transaction costs.

As the access to information and restriction of cooperation are expressed as critical factors for researchers (Bryman 2003), all cases were analysed within a single engineering firm:

- Case study A relates to a detailed engineering design project with a twelve-month duration, for a multinational company aiming to build a consumer goods plant in Brazil;

- Case study B relates to a detailed engineering design project with a fifteen-month duration, for a multinational company aiming to build a food plant in Brazil;

- Case study C relates to a detailed engineering design project with a sixteen-month duration, for a multinational company aiming to build a chemical plant in Brazil;

- Case study D relates to a detailed engineering design project with a five-month duration, for a multinational company aiming to build a sugar and ethanol plant in Brazil.

Once the interviews with the respective project managers of the different cases studied were conducted, the script suggested by Miles and Huberman (1994) was followed, in which the analysis of each case is presented individually on the identification of transaction costs, specifically in industrial construction engineering projects in Brazil.

\subsection{Case study A}

A number of ex-ante and ex-post transaction costs were identified in Case Study A, but it was identified that re- questing clarification of the RFP (Request for Proposal), although not identified as a transaction cost in the literature, is an ex-ante transaction cost since it requires an investment of time for the preparation of the correct questions by the bidder as well as from the owners, for the necessary clarifications.

It was also identified that the preparation of estimates is an ex-ante and ex-post transaction cost since this cost occurs not only in the pre-contractual phase and in the preparation of the proposal itself but also in the preparation of change orders. Consequently, price negotiation is also an ex-ante and ex-post transaction cost, as it occurs both for the sale of the project and for negotiation of change orders by the engineering contractor (engineering firm).

Nevertheless, communication is also an ex-ante and ex-post transaction cost since the way of communicating the proposal, including the project execution plan, was reported by the engineering contractor to be crucial for gaining the project, as well as crucial after contract signature, given the need to keep all interested parties well informed. The coordination of the proposal as a project is also considered an ex-ante and ex-post transaction cost since the proposal preparation is already considered a project itself and must be managed as such, and, likewise, there is a cost to such coordination after the contract has been signed.

The engineering contractor's early involvement was considered as an ex-ante transaction cost since, due to the internal complexity of the owner's organization, it was required that the engineering contractor should be involved in the project before signing the contract, in order to meet the required deadline.

Since the project was considered an unconventional one in the Brazilian industry, it was reported that the learning curve of the project was low, generating very high ex-post transaction costs related to trust, as well as cooperation and conflict management since the owner frequently questioned the ability of the team to execute the respective project with quality and within the required time schedule. The mistrust led to another additional transaction cost related to the creation of a steering council, in which it was established that the senior management of both companies should periodically meet for steering the project to the right direction. However, this cost was not initially estimated by any of the parties, thereby requiring an additional transaction cost of performance monitoring. The lack of previous experience of the engineering contractor in similar projects also caused an important transaction cost.

The completeness of the engineering project was proven to be a high ex-post transaction cost for both parties since the basic engineering design was incomplete and demanded that the engineering contractor, during detail design, increase their transaction costs since successive estimates for change order presentation and price negotiations were required, as well as transaction costs related to the analysis on whether such change orders constituted deviations from the contract. This cost was considered ex-ante and ex-post since it included not only the ex-ante 
cost of superficially analysing the available basic project for estimating the proposal but also the several revisions that were required ex-post for the perfect execution of the detail design.

It was also observed that transaction costs associated with trust and the owner's behaviour were related to another transaction cost associated with the non-existence of a previous relationship and, as the project progressed, with the increase of confidence between both parties, the owner's behaviour became completely different from that behaviour exhibited at the start of the project.

Transaction costs related to hiring and firing were also important, and it could be observed that they were directly related to the availability of resources, required quality, salary level and price pressure during contract negotiation, as the engineering contractor had other major projects happening at the same time, which entailed a necessary hiring of market professionals with salaries in line with the negotiated project sales price. In addition, the owner noted that some professionals of the engineering contractor were not up to the quality required by the project, which required the replacement of some professionals during the project execution, increasing further the pressure for additional hiring in order to meet the delivery of the project within the negotiated time schedule. For this reason, the transaction cost of identifying professionals for the project in the market was considered as ex-ante and ex-post since such costs occurred not only just prior to the contract signature but also afterwards.

\subsection{Case study $B$}

In Case study B, a number of ex-ante and ex-post transaction costs in line with the literature were identified but similar to the situation in Case Study A, it was possible to identify a gap in the literature related to the RFP clarification costs, which are important ex-ante transaction costs, as they often require considerable dedication from the engineering contractor and the owner. It was also identified that the owner often changes strategy during the project execution, as identified by Chang and Qian (2015), but the support of the engineering contractor for such strategic decisions is an important ex-post transaction cost not identified in the literature.

Both companies already had previous relationships with similar project experience, which favoured the learning curve and the formation of the engineering team, thus reducing the respective ex-ante and ex-post transaction costs. However, it was reported by the interviewee that at some point in the project, a high number of quality problems were presented, thus increasing the transaction costs related to performance monitoring and showing that experience in similar projects and previous relationship are not a guarantee of superior quality or lower transaction costs and that the technical competence of those involved is a significant transaction cost to be considered. Hiring new professionals to fill the quality gap was necessary, generating additional transaction costs.
It has also been reported that, in the face of trust, such problems have been amicably overcome with the owner, showing that previous relationships and trust decrease exante and ex-post costs of legal counselling as well as transaction costs related to conflict management. This way, the trust between both companies did not generate a need for a steering council, eliminating such transaction costs.

Despite the similar previous project experience, the project was very specific, which is a situation almost unique in Brazil, and it was found that the ex-post transaction cost for the search for equipment vendors to complete the engineering and investment estimates generated a high transaction cost and that the project schedule initially agreed between the owner and the engineering firm had been for five months. However, by a decision of the owner and through a strategy change, the project was extended for more than twelve months, generating a series of change orders related to the additional team required in the project and to meeting the requirements of the changes requested by the owner. This resulted in transaction costs related to the preparation of estimates, contract deviations analysis, engineering planning, engineering design review and goal setting.

In view of the high number of negotiated change orders discussed, it was reported that the high cost of preparing a good proposal and project management ex-ante are necessary since they reduce the ex-post transaction costs during the negotiation of change orders, thereby increasing the engineering contractor's income and results. It was also reported that the owner's behaviour and a harmonious relationship between owners and the engineering contractor, aligned with good communication and project management, reduced their transaction costs. Thus, it was recorded that good supervision and intra-firm relationships between the participants and the engineering contractor significantly reduced the project's ex-ante and expost transaction costs.

\subsection{Case study C}

A series of ex-ante and ex-post transaction costs could also be identified in Case study $\mathrm{C}$, as identified in the literature but, in line with what was found by Walker and Wing (1999) and Li et al. (2012a, 2012b, 2014), decision-making capacity was proven to be a significant ex-ante and ex-post transaction cost since the lack of authority exhibited by the entity responsible for the owner's procurement activities led to successive commercial and contractual discussions and, thus, increased the transaction costs related to legal counselling, risk, trust, conflict management, emotion, price negotiation, estimation and dispute resolution. All these costs occurred once the purchaser awarded the engineering contractor with the project but, after a few days, his superior indicated that the purchaser was not empowered to do so and that more severe contractual conditions and lower prices were needed.

The engineering contractor, having the information that other competitors had already been informed that 
they had not been awarded, took advantage of an opportunistic and hold-up attitude, showing that the quasi-rent effect can be experienced ex-ante and that this situation was not evidenced in the researched literature.

As part of the respective project was carried out in collaboration with offices of the engineering contractor in another country, transaction costs related to project management, engineering cooperation and completeness were important.

Moreover, communication and an excellent intra-firm relationship were demonstrated to be high transaction costs specifically due to the need for attention and effective communication in a foreign language. Due to this structure, the creation of an international steering meeting with participants from the engineering contractor and owner's headquarters was defined. However, due to the high workload of the two offices from the engineering contractor, periodic meetings rarely occurred and, despite the apparent cost savings of this transaction, this later proved to be a high transaction cost for both partners since several decisions had to be made in order to assure the project time schedule and quality.

Both companies already had previous relationships and recurring business worldwide, but such knowledge transfer from the engineering contractor's parent company to the Brazilian branch did not occur in an effective way, evidencing a gap in the literature that knowledge transfer constitutes an important ex-ante and ex-post transaction cost and that it impacts the time schedule and quality.

In this sense, considering that the engineering contractor had highly qualified professionals allocated to another project, the availability of resources proved to be an important ex-post transaction cost, which directly influenced transaction costs related to contracting and dismissal, as identified by Eccles (1981) and Walker and Wing (1999).

\subsection{Case study D}

A series of ex-ante and ex-post transaction costs were also identified in Case study D, in line with the literature. However, consistent with the previously identified cases, it was reported that requesting clarification of the RFP is an ex-ante transaction cost not identified in the literature, and travels to visit the owner and all the time spent travelling from the office to the headquarters location were exante and ex-post transaction costs not identified in the literature, as in this specific case, several trips were requested for clarification of the bid and for increasing the owner's confidence in the engineering contractor (at this point a bidder) since the companies had no previous relationship. Additionally, it took a considerable amount of travel time during the execution of the project since the customer was in a different state than the engineering contractor.

The owner's technical competence and decision-making capacity increased the ex-ante and ex-post contractor's transaction costs since several topics were frequently not clear in the (RFP), causing rework of the bidder's propos- al, as the owner's senior management decided to change premises that had previously been established by the owner's project team, thereby also impacting the costs related to the owners behaviour. Ex-post, this increased the number of hours spent by the engineering contractor in the project, as the owner often imagined contracting something different from what was in the RFP itself.

Despite the above topics, which generated additional transaction costs, the owner's bidding behaviour helped the engineering contractor to be awarded the project since transparency in conducting the bid process guided the contractor's proposal's deficiencies and indicated where his deficiencies should be adjusted, demonstrating that despite a high transaction cost, his dedication in clarifying the RFP ex-ante helped the engineering contractor to be awarded the project.

It was also noticed that the owners decision-making capacity had a profound impact on the engineering contractor's transaction costs since once the project had been awarded to the engineering contractor, the contract preparation and negotiation procedures including warranties, bonus and penalties requirements started, which had a strong impact on the engineering contractor's exante transaction costs since the negotiations that were imagined to take a week took more than sixty days due to the owners decision-making ability. The contractual terms agreed between both parties changed repeatedly even minutes before the expected signature.

The constant expectation of the contract signature generated very high transaction costs related to the engineering team and the availability of resources since the team remained idle, awaiting the project start.

It is recorded, however, that such idle costs were converted into project know-how once the team was dedicated to understanding the maximum possible project scope and contractual issues, which consequently reduced several ex-post transaction costs. Despite the high cost, this showed that investing ex-ante in understanding the scope and contractual terms reduces ex-post transaction costs.

The owner's decision making capacity, communication, trust, cooperation and intra-firm interaction strongly affected the engineering contractor's transaction costs since the owners indicated that there were internal relationship problems between the contributing agents to the project, which delayed information delivery crucial to making progress, generating a consequent delay.

Thus, the effective complexity of the project and engineering completeness also contributed to additional transaction costs since the basic engineering presented was of low quality and required a larger number of hours to perform the services than previously estimated in the proposal by the engineering contractor. Such uncertainties demanded the creation of a steering meeting between the top management of both companies, increasing the transaction costs for both parties since this had not been originally estimated. 


\section{Cross-case analysis}

The data were tabulated and classified according to the number of times a transaction cost was identified in the projects surveyed, thus allowing a better cross-case analysis. For instances of costs that had three or four occurrences, the occurrence level was considered high, for two occurrences, it was considered average, and for one or none, low.

Within the 87 transaction costs identified in the literature, it was observed that contributors control, non-adaptation costs, incentive management, contribution integration, market research, capital equipment procurement and material replacement were not considered transaction costs in the researched projects. However, three new types of cost that were not identified in the literature were now listed, being related to RFP clarification, knowledge transfer, travel as well as support to strategic decisions of the owner.

Out of the remaining 83 transaction costs identified, 112 cases were considered ex-ante in the four projects surveyed, with sixteen types of costs being considered high frequency (52), eighteen as medium frequency (36) and forty-nine types considered low frequency (24). Ex-post, the number of occurrences was significantly higher, reaching a frequency of 169 , where thirty-two types of cost were considered high frequency (112), seventeen as medium frequency (34) and thirty four as low frequency (23) as shown in Table 2.

The divergence in the number of ex-ante and ex-post frequencies evidenced that transaction costs occurred with greater ex-post intensity in the researched projects, in which experience in similar projects, contractor behavior, legal and financial technical advice, identification of professionals for the project and information occurred with high frequency ex-ante and ex-post, and that the fair allocation of risks, bidding behavior, project preparation cost, feasibility study, bidding clarification, contract negotiation, contract preparation and administration and price pressure during contract negotiation were transaction costs which occurred with high frequency ex-ante, but low frequency ex-post, and that project learning, engineering completeness, trust, hiring and firing, engineering management, contract variances, conflict management, change order negotiation and required quality are costs that occurred with low frequency ex-ante, but high ex-post.

\section{Discussion}

Li et al. (2015) warned that, despite the large-scale recognition of the importance of Transaction Cost Theory (TCT), the construction industry has not given much importance to this subject, which is corroborated by the few papers found in the literature review.

The findings of the present paper may enlighten academics and industry practitioners on how ex-ante and ex-post transaction costs in industrial construction engineering projects are observed and seeks to contribute in- formation to the gap identified by Winch (2001), who indicated that the lack of empirical studies is one of the main criticisms of the studies on transaction costs.

Ex-ante, in all the analysed cases, it was evidenced that the experience in similar projects is an important cost that increases the chances of the proponent to be considered for future contracts since even in cases in which the company did not have the required experience, showing in various ways their experience through past contracts of similar scope or that they had even carried out projects abroad evidenced that the proponents had the skills required for the project, thus impacting transaction costs. Ex-post, this cost mainly refers to the ability to complete the project with higher productivity due to previous experiences.

Technical, legal and financial advice has also been shown as an important ex-ante cost and was identified in all surveyed projects. Ex-post, this was identified in case studies A, B and C since these items always had to be reviewed in the event of change orders negotiation.

The elaboration of estimates was an ex-ante cost that occurred in all projects since logically it was necessary to estimate the cost of the project before sending the proposal to the contractor.

Costs related to uncertainties were also important exante since they were identified in all projects analysed. Uncertainty is an important transaction attribute, as identified by Williamson (1985), and reported in all projects since a great deal of time is consumed in estimating and/ or pricing.

In all the researched cases, it was evidenced that the owners' behaviour is an important ex-post cost since this behaviour is reflected in the evolution of the work, increasing or decreasing costs. Ex-ante, this item was reported as important in case studies B, C and D, showing that it can impact the proposal preparation.

Communication has proved to be an important expost cost and has been reported in all projects, confirming its importance, as identified by Kerzner (2013), who found that among several problems faced in projects, communication is one of the most frequent.

The availability of resources was also pointed out as an ex-post cost in all the analysed cases since it was reported that once the project was awarded, the pressure for meeting the deadline by the owner was immense and that the mobilization of resources did not necessarily happen at the time expected by project managers, for which reason the time schedule was also identified in all projects as an important transaction cost.

Good project management is a key factor for the project's success (PMI 2017), corroborating the result that project management is a significant ex-post cost identified in all projects surveyed. In addition, good management has a direct impact on costs related to contract deviations, negotiation of claims and communication, which are expost transaction costs identified in all projects surveyed.

Choosing well trained professionals for project supervision was also reported in all projects surveyed as an ex-post transaction cost since a good supervisor could influence 
Table 2. Identified transaction costs

\begin{tabular}{|c|c|c|c|c|c|c|c|c|c|c|c|c|c|c|}
\hline \multirow[b]{3}{*}{ Identified costs in the project } & \multicolumn{7}{|c|}{ Ex ante } & \multicolumn{7}{|c|}{ Ex post } \\
\hline & \multicolumn{4}{|c|}{ Project } & \multirow{2}{*}{ 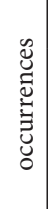 } & \multirow{2}{*}{ 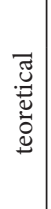 } & \multirow{2}{*}{ 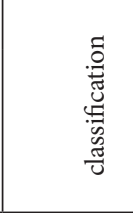 } & \multicolumn{4}{|c|}{ Project } & \multirow{2}{*}{ 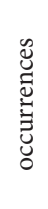 } & \multirow{2}{*}{ 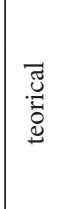 } & \multirow{2}{*}{ 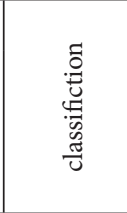 } \\
\hline & A & $\mathrm{B}$ & $\mathrm{C}$ & $\mathrm{D}$ & & & & A & $\mathrm{B}$ & $\mathrm{C}$ & $\mathrm{D}$ & & & \\
\hline Experience in similar projects & $\mathrm{x}$ & $\mathrm{x}$ & $\mathrm{x}$ & $\mathrm{x}$ & 4 & 4 & High & $\mathrm{x}$ & $\mathrm{x}$ & $\mathrm{x}$ & $\mathrm{x}$ & 4 & 4 & High \\
\hline Behavior of the contractor & & $\mathrm{x}$ & $\mathrm{x}$ & $\mathrm{x}$ & 3 & 4 & High & $\mathrm{x}$ & $\mathrm{x}$ & $\mathrm{x}$ & $\mathrm{x}$ & 4 & 4 & High \\
\hline Communication & $\mathrm{x}$ & & & $\mathrm{x}$ & 2 & 2 & Medium & $\mathrm{x}$ & $\mathrm{x}$ & $\mathrm{x}$ & $\mathrm{x}$ & 4 & 4 & High \\
\hline Availability of resources & & $\mathrm{x}$ & & $\mathrm{x}$ & 2 & 2 & Medium & $\mathrm{x}$ & $\mathrm{x}$ & $\mathrm{x}$ & $\mathrm{x}$ & 4 & 4 & High \\
\hline Project management & $\mathrm{x}$ & & & $\mathrm{x}$ & 2 & 2 & Medium & $\mathrm{x}$ & $\mathrm{x}$ & $\mathrm{x}$ & $\mathrm{x}$ & 4 & 4 & High \\
\hline Deadline & & & $\mathrm{x}$ & $\mathrm{x}$ & 2 & 2 & Medium & $\mathrm{x}$ & $\mathrm{x}$ & $\mathrm{x}$ & $\mathrm{x}$ & 4 & 4 & High \\
\hline Supervision & & $\mathrm{x}$ & & $\mathrm{x}$ & 2 & 2 & Medium & $\mathrm{x}$ & $\mathrm{x}$ & $\mathrm{x}$ & $\mathrm{x}$ & 4 & 4 & High \\
\hline Project learning & & & & $\mathrm{x}$ & 1 & 1 & Low & $\mathrm{x}$ & $\mathrm{x}$ & $\mathrm{x}$ & $\mathrm{x}$ & 4 & 4 & High \\
\hline Engineering completeness & & & $\mathrm{x}$ & & 1 & 1 & Low & $\mathrm{x}$ & $\mathrm{x}$ & $\mathrm{x}$ & $\mathrm{x}$ & 4 & 4 & High \\
\hline Confiability & & & $\mathrm{x}$ & & 1 & 1 & Low & $\mathrm{x}$ & $\mathrm{x}$ & $\mathrm{x}$ & $\mathrm{x}$ & 4 & 4 & High \\
\hline Hiring and firing & & & & $\mathrm{x}$ & 1 & 1 & Low & $\mathrm{x}$ & $\mathrm{x}$ & $\mathrm{x}$ & $\mathrm{x}$ & 4 & 4 & High \\
\hline Engineering management & & & & $\mathrm{x}$ & 1 & 1 & Low & $\mathrm{x}$ & $\mathrm{x}$ & $\mathrm{x}$ & $\mathrm{x}$ & 4 & 4 & High \\
\hline Contract deviation & & & & & 0 & 1 & Low & $\mathrm{x}$ & $\mathrm{x}$ & $\mathrm{x}$ & $\mathrm{x}$ & 4 & 4 & High \\
\hline Conflict management & & & & & 0 & 1 & Low & $\mathrm{x}$ & $\mathrm{x}$ & $\mathrm{x}$ & $\mathrm{x}$ & 4 & 4 & High \\
\hline Negotiation & & & & & 0 & 1 & Low & $\mathrm{x}$ & $\mathrm{x}$ & $\mathrm{x}$ & $\mathrm{x}$ & 4 & 4 & High \\
\hline Quality required & & & & & 0 & 1 & Low & $\mathrm{x}$ & $\mathrm{x}$ & $\mathrm{x}$ & $\mathrm{x}$ & 4 & 4 & High \\
\hline Technical, legal and financial advice & $\mathrm{x}$ & $\mathrm{x}$ & $\mathrm{x}$ & $\mathrm{x}$ & 4 & 4 & High & $\mathrm{x}$ & $\mathrm{x}$ & $\mathrm{x}$ & & 3 & 4 & High \\
\hline Identification of project professionals & $\mathrm{x}$ & & $\mathrm{x}$ & $\mathrm{x}$ & 3 & 4 & High & $\mathrm{x}$ & $\mathrm{x}$ & $\mathrm{x}$ & & 3 & 4 & High \\
\hline Information & & $\mathrm{x}$ & $\mathrm{x}$ & $\mathrm{x}$ & 3 & 4 & High & & $\mathrm{x}$ & $\mathrm{x}$ & $\mathrm{x}$ & 3 & 4 & High \\
\hline Relationship intra company & & $\mathrm{x}$ & $\mathrm{x}$ & & 2 & 2 & Medium & & $\mathrm{x}$ & $\mathrm{x}$ & $\mathrm{x}$ & 3 & 4 & High \\
\hline Relationship contractor/hired & & $\mathrm{x}$ & & $\mathrm{x}$ & 2 & 2 & Medium & $\mathrm{x}$ & $\mathrm{x}$ & & $\mathrm{x}$ & 3 & 4 & High \\
\hline Change order & & & $\mathrm{x}$ & & 1 & 1 & Low & $\mathrm{x}$ & $\mathrm{x}$ & & $\mathrm{x}$ & 3 & 4 & High \\
\hline Cooperation & & & & $\mathrm{x}$ & 1 & 1 & Low & $\mathrm{x}$ & & $\mathrm{x}$ & $\mathrm{x}$ & 3 & 4 & High \\
\hline Future business & & $\mathrm{x}$ & & & 1 & 1 & Low & & $\mathrm{x}$ & $\mathrm{x}$ & $\mathrm{x}$ & 3 & 4 & High \\
\hline Engineering planning & & & & $\mathrm{x}$ & 1 & 1 & Low & $\mathrm{x}$ & $\mathrm{x}$ & & $\mathrm{x}$ & 3 & 4 & High \\
\hline Engineering Design Review & $\mathrm{x}$ & & & & 1 & 1 & Low & $\mathrm{x}$ & $\mathrm{x}$ & & $\mathrm{x}$ & 3 & 4 & High \\
\hline Project delay & & & & & 0 & 1 & Low & & $\mathrm{x}$ & $\mathrm{x}$ & $\mathrm{x}$ & 3 & 4 & High \\
\hline Manager advice & & & & & 0 & 1 & Low & $\mathrm{x}$ & & $\mathrm{x}$ & $\mathrm{x}$ & 3 & 4 & High \\
\hline Governance structure & & & & & 0 & 1 & Low & $\mathrm{x}$ & & $\mathrm{x}$ & $\mathrm{x}$ & 3 & 4 & High \\
\hline Subcontracted management & & & & & 0 & 1 & Low & $\mathrm{x}$ & & $\mathrm{x}$ & $\mathrm{x}$ & 3 & 4 & High \\
\hline Preserve governance structure & & & & & 0 & 1 & Low & $\mathrm{x}$ & & $\mathrm{x}$ & $\mathrm{x}$ & 3 & 4 & High \\
\hline Organize governance structure & & & & & 0 & 1 & Low & $\mathrm{x}$ & & $\mathrm{x}$ & $\mathrm{x}$ & 3 & 4 & High \\
\hline Elaboration of estimates & $\mathrm{x}$ & $\mathrm{x}$ & $\mathrm{x}$ & $\mathrm{x}$ & 4 & 4 & High & $\mathrm{x}$ & $\mathrm{x}$ & & & 2 & 2 & Medium \\
\hline Uncertainties & $\mathrm{x}$ & $\mathrm{x}$ & $\mathrm{x}$ & $\mathrm{x}$ & 4 & 4 & High & & $\mathrm{x}$ & & $\mathrm{x}$ & 2 & 2 & Medium \\
\hline Price negociations & $\mathrm{x}$ & $\mathrm{x}$ & $\mathrm{x}$ & & 3 & 4 & High & $\mathrm{x}$ & $\mathrm{x}$ & & & 2 & 2 & Medium \\
\hline Capacity of decisions & & & $\mathrm{x}$ & $\mathrm{x}$ & 2 & 2 & Medium & & & $\mathrm{x}$ & $\mathrm{x}$ & 2 & 2 & Medium \\
\hline Organizational efficiency & $\mathrm{x}$ & $\mathrm{x}$ & & & 2 & 2 & Medium & & $\mathrm{x}$ & $\mathrm{x}$ & & 2 & 2 & Medium \\
\hline Assemble engineering team & $\mathrm{x}$ & & & $\mathrm{x}$ & 2 & 2 & Medium & & $\mathrm{x}$ & & $\mathrm{x}$ & 2 & 2 & Medium \\
\hline Technical competence & & & & $\mathrm{x}$ & 1 & 1 & Low & & $\mathrm{x}$ & & $\mathrm{x}$ & 2 & 2 & Medium \\
\hline Organizational structure & $\mathrm{x}$ & & & & 1 & 1 & Low & & & $\mathrm{x}$ & $\mathrm{x}$ & 2 & 2 & Medium \\
\hline Hold up & & & $\mathrm{x}$ & & 1 & 1 & Low & & $\mathrm{x}$ & $\mathrm{x}$ & & 2 & 2 & Medium \\
\hline Bounty (bonus and bad) & & & & $\mathrm{x}$ & 1 & 1 & Low & & & $\mathrm{x}$ & $\mathrm{x}$ & 2 & 2 & Medium \\
\hline Frequency of lawsuits & & & & & 0 & 1 & Low & & $\mathrm{x}$ & & $\mathrm{x}$ & 2 & 2 & Medium \\
\hline Impossibility of future cooperation & & & & & 0 & 1 & Low & & & $\mathrm{x}$ & $\mathrm{x}$ & 2 & 2 & Medium \\
\hline Interaction engineering/construction & & & & & 0 & 1 & Low & $\mathrm{x}$ & & $\mathrm{x}$ & & 2 & 2 & Medium \\
\hline Performance monitoring & & & & & 0 & 1 & Low & $\mathrm{x}$ & $\mathrm{x}$ & & & 2 & 2 & Medium \\
\hline Engineering project & & & & & 0 & 1 & Low & & $\mathrm{x}$ & & $\mathrm{x}$ & 2 & 2 & Medium \\
\hline
\end{tabular}


End of Table 2

\begin{tabular}{|c|c|c|c|c|c|c|c|c|c|c|c|c|c|c|}
\hline \multirow[b]{3}{*}{ Identified costs in the project } & \multicolumn{7}{|c|}{ Ex ante } & \multicolumn{7}{|c|}{ Ex post } \\
\hline & \multicolumn{4}{|c|}{ Project } & \multirow{2}{*}{ 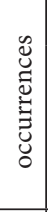 } & \multirow{2}{*}{$\begin{array}{l}\overrightarrow{\widetilde{U}} \\
\stackrel{\mathscr{D}}{0} \\
\stackrel{0}{ \pm}\end{array}$} & \multirow{2}{*}{ 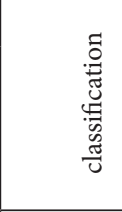 } & \multicolumn{4}{|c|}{ Project } & \multirow{2}{*}{ 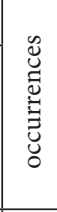 } & \multirow[b]{2}{*}{ 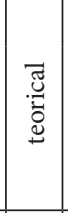 } & \multirow{2}{*}{ 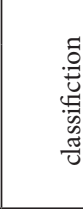 } \\
\hline & A & B & $\mathrm{C}$ & $\mathrm{D}$ & & & & A & $\mathrm{B}$ & $\mathrm{C}$ & $\mathrm{D}$ & & & \\
\hline Fair allocation of risks & $\mathrm{x}$ & & $\mathrm{x}$ & $\mathrm{x}$ & 3 & 4 & High & $\mathrm{x}$ & & & & 1 & 1 & Low \\
\hline Illicit behavior & & $\mathrm{x}$ & $\mathrm{x}$ & $\mathrm{x}$ & 3 & 4 & High & $\mathrm{x}$ & & & & 1 & 1 & Low \\
\hline Costs of project preparation & $\mathrm{x}$ & $\mathrm{x}$ & $\mathrm{x}$ & & 3 & 4 & High & & $\mathrm{x}$ & & & 1 & 1 & Low \\
\hline Viability studies & $\mathrm{x}$ & & $\mathrm{x}$ & $\mathrm{x}$ & 3 & 4 & High & & $\mathrm{x}$ & & & 1 & 1 & Low \\
\hline Emotion & & $\mathrm{x}$ & $\mathrm{x}$ & & 2 & 2 & Medium & & & $\mathrm{x}$ & & 1 & 1 & Low \\
\hline Bargaining power & $\mathrm{x}$ & $\mathrm{x}$ & & & 2 & 2 & Medium & & $\mathrm{x}$ & & & 1 & 1 & Low \\
\hline Relationship old client/ subcontracted & & $\mathrm{x}$ & & $\mathrm{x}$ & 2 & 2 & Medium & & $\mathrm{x}$ & & & 1 & 1 & Low \\
\hline Warranty requirements & $\mathrm{x}$ & & & $\mathrm{x}$ & 2 & 2 & Medium & & & $\mathrm{x}$ & & 1 & 1 & Low \\
\hline Leadership capacity & & & & $\mathrm{x}$ & 1 & 1 & Low & & & & $\mathrm{x}$ & 1 & 1 & Low \\
\hline Effective complexity & & & & $\mathrm{x}$ & 1 & 1 & Low & & & & $\mathrm{x}$ & 1 & 1 & Low \\
\hline Bargain costs & & $\mathrm{x}$ & & & 1 & 1 & Low & & $\mathrm{x}$ & & & 1 & 1 & Low \\
\hline Overhead & $\mathrm{x}$ & & & & 1 & 1 & Low & & & $\mathrm{x}$ & & 1 & 1 & Low \\
\hline Reputation & & & & $\mathrm{x}$ & 1 & 1 & Low & & & & $\mathrm{x}$ & 1 & 1 & Low \\
\hline Knowledge transference (not identified in literature) & & & $\mathrm{x}$ & & 1 & 1 & Low & & & $\mathrm{x}$ & & 1 & 1 & Low \\
\hline Travels (not identified in literature) & & & & $\mathrm{x}$ & 1 & 1 & Low & & & & $\mathrm{x}$ & 1 & 1 & Low \\
\hline Hired behavior & & & & & 0 & 1 & Low & & $\mathrm{x}$ & & & 1 & 1 & Low \\
\hline Constructiveness & & & & & 0 & 1 & Low & & & $\mathrm{x}$ & & 1 & 1 & Low \\
\hline Judge executions & & & & & 0 & 1 & Low & & & $\mathrm{x}$ & & 1 & 1 & Low \\
\hline Bad relationship (payments in time, interaction, etc) & & & & & 0 & 1 & Low & & & $\mathrm{x}$ & & 1 & 1 & Low \\
\hline Payments in time & & & & & 0 & 1 & Low & & & $\mathrm{x}$ & & 1 & 1 & Low \\
\hline Look for providers & & & & & 0 & 1 & Low & & $\mathrm{x}$ & & & 1 & 1 & Low \\
\hline Qualification of hired & & & & & 0 & 1 & Low & & $\mathrm{x}$ & & & 1 & 1 & Low \\
\hline Dispute resolution & & & & & 0 & 1 & Low & & & $\mathrm{x}$ & & 1 & 1 & Low \\
\hline $\begin{array}{l}\text { Clarification of the public notice (not identified in } \\
\text { literature) }\end{array}$ & $\mathrm{x}$ & $\mathrm{x}$ & & $\mathrm{x}$ & 3 & 4 & High & & & & & 0 & 1 & Low \\
\hline Contracts negociation & & $\mathrm{x}$ & $\mathrm{x}$ & $\mathrm{x}$ & 3 & 4 & High & & & & & 0 & 1 & Low \\
\hline Contract preparation and management & $\mathrm{x}$ & & $\mathrm{x}$ & $\mathrm{x}$ & 3 & 4 & High & & & & & 0 & 1 & Low \\
\hline Pressure of prices in contracts negociation & $\mathrm{x}$ & $\mathrm{x}$ & & $\mathrm{x}$ & 3 & 4 & High & & & & & 0 & 1 & Low \\
\hline Competition between bidders & & & $\mathrm{x}$ & $\mathrm{x}$ & 2 & 2 & Medium & & & & & 0 & 1 & Low \\
\hline Definition of policies and objectives & $\mathrm{x}$ & & $\mathrm{x}$ & & 2 & 2 & Medium & & & & & 0 & 1 & Low \\
\hline Project identification & $\mathrm{x}$ & & & $\mathrm{x}$ & 2 & 2 & Medium & & & & & 0 & 1 & Low \\
\hline Preparation and avaliation of public notices & $\mathrm{x}$ & & & $\mathrm{x}$ & 2 & 2 & Medium & & & & & 0 & 1 & Low \\
\hline Early involvement of hired & $\mathrm{x}$ & & & & 1 & 1 & Low & & & & & 0 & 1 & Low \\
\hline Financial oportunity & $\mathrm{x}$ & & & & 1 & 1 & Low & & & & & 0 & 1 & Low \\
\hline Support in strategics clients decisions & & $\mathrm{x}$ & & & 1 & 1 & Low & & & & & 0 & 1 & Low \\
\hline Control of taxpayers & & & & & 0 & 1 & Low & & & & & 0 & 1 & Low \\
\hline Costs of non-adaptation & & & & & 0 & 1 & Low & & & & & 0 & 1 & Low \\
\hline Incentives management & & & & & 0 & 1 & Low & & & & & 0 & 1 & Low \\
\hline Contributions integration & & & & & 0 & 1 & Low & & & & & 0 & 1 & Low \\
\hline Market research & & & & & 0 & 1 & Low & & & & & 0 & 1 & Low \\
\hline Look for capital equipments & & & & & 0 & 1 & Low & & & & & 0 & 1 & Low \\
\hline Replacement of materials & & & & & 0 & 1 & Low & & & & & 0 & 1 & Low \\
\hline
\end{tabular}


the costs related to time schedule, project learning, trust, hiring and firing, engineering management, conflict management and required quality, which were also identified as ex-post transaction costs in all surveyed projects.

Finally, the completeness of the engineering received by the company, translated as the previous studies carried out by the owner, meant a significant transaction cost in all the surveyed projects since the contractor frequently indicated in the RFP that certain studies would be available ex-post, but this transfer did not actually take place, which consequently required change orders negotiations.

In view of the above, it has been shown that the objective of the present research has been reached since it was possible to identify, in line with the researched literature, a series of ex-ante and ex-post transaction costs in industrial construction engineering projects in Brazil. In addition, travel, RFP clarification, support for strategic decisions of the owner and knowledge transfer have also been identified as transaction costs not identified in the researched literature but with high relevance to the respective subject.

\section{Conclusions, limitations and future work}

The present work, through empirical research, contributed to the scientific knowledge in the area of industrial engineering and operations management by shedding light on ex-ante and ex-post transaction costs in different industrial construction engineering projects among several industrial sectors, thus allowing an improvement of results in future projects when taking into account the possibility of such costs occurring.

It was also identified that although Winch's (2001) finding in the United Kingdom that the possibility of future relationships outweighs the possibility of an opportunistic attitude has been corroborated in all projects, it remains to be seen if the bargaining power of the contractor can be used to exercise the possibility of quasi-rent due specifically to the possibility of future relationships between the owner and the engineering contractor.

This work was limited to the research of four case studies; all of these were detailed engineering projects for industrial construction carried out by a single company in Brazil, thus not allowing the generalization of the results obtained. It is suggested that a new research should be carried out addressing industrial sectors different from those surveyed in the present study, as well as those related to residential construction and infrastructure sectors in Brazil or in other countries. It is also suggested that new research be conducted to identify whether conceptual or basic engineering projects could present different transaction costs, as well as to determine the effective measurement of such costs in all types of projects.

\section{Disclosure Statement}

Authors to declare not have any competing financial, professional, or personal interests from other parties.

\section{Acknowledgements}

The authors would like to thank Universidade Nove de Julho and the surveyed company for providing the required support needed for this research.

\section{References}

Alchian, A. A.; Woodward, S. 1988. The firm is dead; long live the firm a review of Oliver E. Williamson's the economic institutions of capitalism, Journal of Economic Literature 26(1): 65-79.

Bajari, P.; Tadelis, S. 2001. Incentives versus transaction costs: A theory of procurement contracts, Rand Journal of Economics 32(3): 387-407. https://doi.org/10.2307/2696361

Batavia, R. 2001. Front-end loading for life cycle success, in Offshore Technology Conference, 2001. Houston: OTC. https://doi.org/10.4043/12980-MS

Bryman, A. 2003. Quantity and quality in social research. Routledge.

Chang, C. Y.; Ive, G. 2007. Reversal of bargaining power in construction projects: meaning, existence and implications, Construction Management and Economics 25(8): 845-855. https://doi.org/10.1080/01446190601164113

Chang, C. Y.; Qian, Y. 2015. An econometric analysis of holdup problems in construction projects, Journal of Construction Engineering and Management 141(6): 04015004.

https://doi.org/10.1061/(ASCE)CO.1943-7862.0000957

Coase, R. H. 1937. The nature of the firm, Economica 4: 386-405. https://doi.org/10.1111/j.1468-0335.1937.tb00002.x

Eccles, R. G. 1981. The quasifirm in the construction industry, Journal of Economic Behavior \& Organization 2(4): 335-357. https://doi.org/10.1016/0167-2681(81)90013-5

Eisenhardt, K. M. 1989. Building theories from case study research, Academy of Management Review 14(4): 532-550. https://doi.org/10.5465/amr.1989.4308385

ENR. 2017. Top 500 design firms [online], [cited 1 September 2017]. Available from Internet: http://www.enr.com/ toplists/2017-Top-500-Design-Firms1

Farajian, M. 2010. Transaction cost estimation model for us infrastructure public private partnerships: MS thesis. University of Maryland, College Park, MD.

Formoso, C. T.; Sommer, L.; Koskela, L.; Isatto, E. L. 2011. An exploratory study on the measurement and analysis of makingdo in construction sites, in Annual Conference of the International Group for Lean Construction, Peru, Lima. https://doi.org/10.13140/RG.2.1.4753.1043

Guo, L.; Li, H.; Li, P.; Zhang, C. 2016. Transaction costs in construction projects under uncertainty, Kybernetes 45(6): 866883. https://doi.org/10.1108/K-10-2014-0206

Ho, P.; Tsui, C. W. 2009. The transaction cost of public private partnerships: implications on PPP governance design, in Proceedings of the ASCE LEAD Speciality Conference Global Governance in Project Organizations, November 2009, South Lake Tahoe, California, 5-7.

Isatto, E. L.; Formoso, C. T. 2011. An exploratory study on the measurement and analysis of making-do in construction sites, in Annual Conference of the International Group for Lean Construction, 2011.

Jiang, W.; Jiang, W.; Lu, Y.; Lu, Y. 2017. Influence of initial trust on control from client perspective: construction industry in China, Engineering, Construction and Architectural Management 24(2): 326-345.

https://doi.org/10.1108/ECAM-11-2015-0180 
Jobin, D. 2008. A transaction cost-based approach to partnership performance evaluation, Evaluation 14(4): 437-465. https://doi.org/10.1177/1356389008095487

Kerzner, H. 2013. Project management: a systems approach to planning, scheduling, and controlling. John Wiley \& Sons.

Lai, L. W. C. 2000. The Coasian market-firm dichotomy and subcontracting in the construction industry, Construction Management and Economics 18(3): 355-362. https://doi.org/10.1080/014461900370717

Lee, H. S.; Seo, J. O.; Park, M.; Ryu, H. G.; Kwon, S. S. 2009. Transaction-cost-based selection of appropriate general contractor-subcontractor relationship type, Journal of Construction Engineering and Management 135(11): 1232-1240. https://doi.org/10.1061/(ASCE)CO.1943-7862.0000086

Li, H.; Arditi, D.; Wang, Z. 2012a. Transaction-related issues and construction project performance, Construction Management and Economics 30(2): 151-164. https://doi.org/10.1080/01446193.2012.655254

Li, H.; Arditi, D.; Wang, Z. 2012b. Factors that affect transaction costs in construction projects, Journal of Construction Engineering and Management 139(1): 60-68. https://doi.org/10.1061/(ASCE)CO.1943-7862.0000573

Li, H.; Arditi, D.; Wang, Z. 2014. Transaction costs incurred by construction owners, Engineering, Construction and Architectural Management 21(4): 444-458. https://doi.org/10.1108/ECAM-07-2013-0064

Li, H.; Arditi, D.; Wang, Z. 2015. Determinants of transaction costs in construction projects, Journal of Civil Engineering and Management 21(5): 548-558.

https://doi.org/10.3846/13923730.2014.897973

Lingard, H.; Hughes, W.; Chinyio, E. 1998. The impact of contractor selection method on transaction costs: a review, Journal of Construction Procurement 4(2): 89-102.

Lu, P.; Guo, S.; Qian, L.; He, P.; Xu, X. 2015a. The effectiveness of contractual and relational governances in construction projects in China, International Journal of Project Management 33(1): 212-222. https://doi.org/10.1016/j.ijproman.2014.03.004

Lu, P.; Qian, L.; Chu, Z.; Xu, X. 2015b. Role of opportunism and trust in construction projects: Empirical evidence from China, Journal of Management in Engineering 32(2): 05015007. https://doi.org/10.1061/(ASCE)ME.1943-5479.0000401

Lynch, T. D. 1996. A transaction cost framework for evaluating construction project organization: Doctoral dissertation. Pennsylvania State University, University Park, PA.

Miles, M. B.; Huberman, A. M. 1994. Qualitative data analysis: An expanded sourcebook. Sage.

Miller, C. J. M.; Packham, G. A.; Thomas, B. C. 2002. Harmonization between main contractors and subcontractors: a prerequisite for lean construction? Journal of Construction Resources 3(1): 67-82. https://doi.org/10.1142/S1609945102000059

Muller, R.; Turner, J. R. 2005. The impact of principal-agent relationship and contract type on communication between project owner and manager, International Journal of Project Management 23(5): 398-403.

https://doi.org/10.1016/j.ijproman.2005.03.001

Palaneeswaran, E.; Kumaraswamy, M.; Rahman, M.; Ng, T. 2003. Curing congenital construction industry disorders through relationally integrated supply chains, Building and Environment 38(4): 571-582.

https://doi.org/10.1016/S0360-1323(02)00188-9
Pang, H. Y.; Cheung, S. O.; Choi, M. C.; Chu, S. Y. 2015. Opportunism in construction contracting: minefield and manifestation, International Journal of Project Organization and Management 7(1): 31-55. https://doi.org/10.1504/IJPOM.2015.068004

Project Management Institute (PMI). 2017. Project Management Professional (PMP) [online], [cited 23 April 2017]. Available from Internet: https://www.pmi.org/certifications/types/project-management-pmp

Reve, T.; Levitt, R. E. 1984. Organization and governance in construction, International Journal of Project Management 2(1): 17-25. https://doi.org/10.1016/0263-7863(84)90054-1

Solino, A. S.; Gago de Santos, P. 2009. Transaction costs in PPP transport infrastructure projects. Working paper. Luxembourg: European Investment Bank.

Walker, A.; Wing, K. C. 1999. The relationship between construction project management theory and transaction cost economics, Engineering, Construction and Architectural Management 6(2): 166-176. https://doi.org/10.1108/eb021109

Whittington, J. M. 2008. The transaction cost economics of highway project delivery: design-build contracting in three states: Doctoral dissertation. University of California, Berkeley, CA.

Williamson, O. E. 1975. Markets and hierarchies: Analysis and antitrust implications: A study in the economics of internal organization. University of Illinois at Urbana-Champaign's Academy for Entrepreneurial Leadership Historical Research Reference in Entrepreneurship.

Williamson, O. E. 1979. Transaction-cost economics: the governance of contractual relations, The Journal of Law and Economics 22(2): 233-261. https://doi.org/10.1086/466942

Williamson, O. E. 1985. The economic institutions of capitalism. Simon and Schuster.

Winch, G. 1989. The construction firm and the construction project: A transaction cost approach, Construction Management and Economics 7(4): 331-345. https://doi.org/10.1080/01446198900000032

Winch, G. M. 2001. Governing the project process: a conceptual framework, Construction Management and Economics 19(8): 799-808. https://doi.org/10.1080/01446190110074264

Winch, G. M. 2015. Project organizing as a problem in information, Construction Management and Economics 33(2): 106116. https://doi.org/10.1080/01446193.2015.1021703

Yin, R. K. 2015. Qualitative research from start to finish. Guilford Publications.

Zerjav, V.; Hartmann, T.; Javernick-Will, A. 2011. Internal governance of design and engineering: The case of the multinational firm, Journal of Construction Engineering and Management 138(1): 135-143.

https://doi.org/10.1061/(ASCE)CO.1943-7862.0000417 